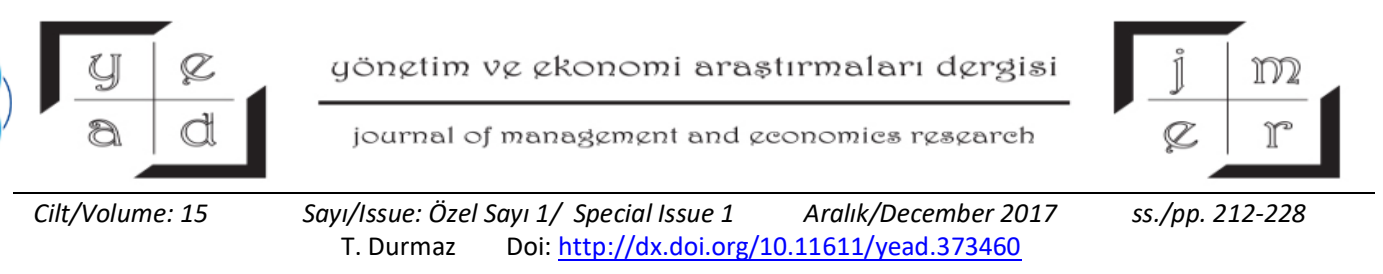

\title{
STRATEGIC DYNAMIC CLIMATE POLICY: THE ROLE OF CCS ${ }^{1}$
}

\section{Dr. Tunç DURMAZ*}

\begin{abstract}
The paper examines the role of carbon capture and storage (CCS) technology first in an exogenous, and then, in an endogenous growth model with environmental constraints. In the first part, we investigate the activity of the CCS systems given an exhaustible resource constraint and limited $\mathrm{CO}_{2}$ storage capacity under climate stabilization targets. In the second section, we look at the activity of the CCS technology and corresponding research and development $(R \& D)$ investments. Our findings indicate that the CCS technology is welfare improving but its level of activity is highly affected by resource and storage constraints. Given the low amount of resources allocated for CCS R\&D, it can be considered that learning-by-doing ( $L b D)$ is more relevant for the CCS technology. This is because all components of CCS systems exist and are in use today by the fossil fuel extraction and refining industries. Yet, CCS has not been applied at scale to a large and operational commercial fossil fuel power plant, indicating that the technology can significantly benefit from LbD. Uncertainties in the political will towards tax rates, and leakage possibilities of the stored $\mathrm{CO}_{2}$ are issues that are left for further research.
\end{abstract}

Key Words: Carbon Capture and Storage, Fossil Fuel Energy, Exogenous Technical Change, Endogenous Technical Change, Climate Change

JEL Classification: H23, O31, Q43, Q54, Q55

\section{STRATEJIKK DİNAMİK İKLIMM POLITTIKASI: KYD’NIN ROLÜ}

\section{ÖZ}

Çalışmada, karbon yakalama ve depolama (KYD) teknolojisin öncelikle dı̧ssal ve sonrasında da içsel bir büyüme modelindeki rolü çevresel kisitlar göz önünde bulundurularak incelenmektedir. İlk bölümde, enerji kaynaklarının tükenebilirliği ve yakalanan karbondioksidin depolanma kapasitesi göz önünde bulundurularak, KYD sistemlerinin faaliyetleri 450 ve 550 ppmv denge ve istikrar hedefleri doğrultusunda araştırılmaktadır. İkinci bölümde, KYD teknolojisinin aktivite derecesine ve ilgili

\footnotetext{
${ }^{1}$ The first draft of this paper is presented ICOAEF 2017 conference on 06-07 December 2017.

*Department of Economics, Yildiz Technical University, Istanbul. Email: tdurmaz@ yildiz.edu.tr
} 
Yönetim ve Ekonomi Arastırmaları Dergisi / Journal of Management and Economics Research

Cilt/Volume: 15 Sayı/Issue: Özel Sayı 1/Special Issue 1 Aralık/December 2017 ss./pp. 212-228

T. Durmaz Doi: http://dx.doi.org/10.11611/yead.373460

araştırma ve geliştirme (AR-GE) harcamalarının etkinliğine bakllmaktadır. Bulgularımız, KYD teknolojisinin kullanımının refah düzeyini arttı̆̆ını göstermekle beraber bu teknolojinin tükenebilir kaynak seviyesinden ve depolama kısıtlamalarından oldukça etkilendiğini ortaya koymaktadır. Sonuçlardan hareketle, KYD'nin AR-GE harcamaları için ayrılan düşük kaynak miktarı göz önüne alındığında, yaparak öğrenmenin (LbD’nin) KYD teknolojisi için daha uygun olduğu görülmektedir. Bunun basilica nedeni olarak KYD sistemlerinin tüm bileşenlerinin günümüzde mevcut olmast ve fosil yakıt çıkarma ve rafine etme endüstrileri tarafindan kullanılması gösterilebilir. Bununla birlikte, KYD, henüz büyük ölçekli, faal ve ticari faaliyet içerisinde olan bir fosil yakttl enerji santraline tam anlamıyla uygulanmamış olduğundan, teknolojinin LbD'den önemli ölçüde faydalanma potansiyeli gözükmektedir. Karbon vergisi oranlarına yönelik siyasi belirsizlikler ve depolanan karbondioksidin atmosfere sızma olasilıkları gibi konular daha ileriki bir araştırmaya bırakılmıştır.

Anahtar Kelimeler: Karbon Yakalama ve Depolama, Fosil Yakıtlar, Dışsal Teknolojik Değişsim, İçsel Teknolojik Değişim, İklim Değişikliği

Jel Sinıflandırmast: H23, O31, Q43, Q54, Q55

\section{INTRODUCTION}

Fossil fuels account for a major share of global anthropogenic greenhouse gas (GHG) emissions and still supply over $80 \%$ of all primary energy needs (IEA, 2014). According to U.S. Energy Information Administration, fossil fuels will remain the primary energy source for the decades to come (IEA, 2013). In the absence of specific actions, however, $\mathrm{CO}_{2}$ concentration in the atmosphere will continue to grow, which can prove catastrophic for the generations to come (UNEP, 2006). Therefore, there is a demand for new technologies that can help with the fight against climate change.

One example for such technologies is carbon capture and storage (CCS). It is considered as a vital technology that can contribute significantly to the efforts in limiting emissions. CCS can be used by large stationary point sources, such as a coal-fired power plant, and emission- intensive industrial facilities, such as cement production. Its main goal is to prevent $\mathrm{CO}_{2}$ emissions of a power plant from entering the atmosphere. Rates of $\mathrm{CO}_{2}$ emissions that are captured can get as high as $85-95 \%$ (Metz et al., 2005).

As of today, there exist three methods for capturing $\mathrm{CO}_{2}$ emissions. Post-combustion removes the $\mathrm{CO}_{2}$ after combustion takes place. In this process, $\mathrm{CO}_{2}$ is separated from the flue gases by using a liquid 
Yönetim ve Ekonomi Arastırmaları Dergisi / Journal of Management and Economics Research

Cilt/Volume: 15 Sayı/Issue: Özel Sayı 1/Special Issue 1 Aralık/December 2017 ss./pp. 212-228

T. Durmaz Doi: http://dx.doi.org/10.11611/yead.373460

solvent. In pre-combustion, the fuel is converted into a mix of $\mathrm{CO}_{2}$ and hydrogen. The latter gas is then burned to produce electricity. The burning of fuel is basically the reaction of fuel with oxygen in the air. Yet, in the oxy-fuel combustion process, the fuel is burned by pure oxygen. The result is a flue stream of $\mathrm{CO}_{2}$ and water vapor. Because there is no nitrogen present in the flue gas, $\mathrm{CO}_{2}$ can be easily captured in this process. (Golombek et al., 2011; Metz et al., 2005).

The CCS technology is envisaged to be a fundamental part of the lowest-cost GHG mitigation policy. In its Technology Roadmap, the International Energy Agency (IEA, 2009, p.4) concludes that without the technology the overall cost to reduce emission to 2005 levels by 2050 increases by $70 \%$." Furthermore, CCS can provide $15 \%$ to 55\% of the cumulative mitigation effort up to 2100 (IPCC, 2005, p.12).

We observe that high-income oil and gas producing countries in Europe and North America use resources on R\&D of CCS technologies. Tjernshaugen (2008) shows that fossil fuel reserves and their extraction activities are the main variables that explain R\&D funding for CCS. Among these countries, Canada and Norway show the strongest contributions. The shares of $R \& D$ budgets to the total $R \& D$ spending in 2005 were $38.79 \%$ and $6.23 \%$ for Nor- way and Canada, respectively (Tjernshaugen, 2008). Nevertheless, there are still questions regarding the economics of CCS and the uncertainties that surrounds the technology.

It is therefore important to show the feasibility of CCS activity and its R\&D from the perspective of a benevolent planner, and see how much this overlaps with the contemporary global political agenda. For this purpose in Section 2, we present a growth model initially with exogenous and then endogenous technical change. The technology for the final good is labor augmenting, while the technology for CCS is capital augmenting. R\&D investments are made using a portion of the final good. In this section we also present the first order conditions and an evaluation of them. In Section 3 we do the calibration. Section 4.1 presents the results for exogenous technical change under different scenarios including constraints like a ceiling on the volume of $\mathrm{CO}_{2}$ in the atmosphere, limited resource stock and limited storage space for injecting the $\mathrm{CO}_{2}$ captured. Section 4.2 presents the results with endogenous technical change. In Section 5 we conclude.

\section{MODEL STRUCTURE}

The analysis will be from a social planner's perspective. Hence, we are not going to deal with issues like imperfect appropriability of $R \& D$ efforts etc. There is a representative agent, representing the whole population. Final good, $\mathrm{Y}_{\mathrm{t}}$, represents the global gross domestic product (GDP). There are three factors 
Yönetim ve Ekonomi Arastırmaları Dergisi / Journal of Management and Economics Research

Cilt/Volume: 15 Sayı/Issue: Özel Sayı 1/Special Issue 1 Aralık/December 2017 ss./pp. 212-228

T. Durmaz Doi: http://dx.doi.org/10.11611/yead.373460

of production for the final output: a capital good (capital), exhaustible resource stock (equivalent to energy here), and labor. The final good production technology exhibits constant returns to scale.

CCS is a capital-intensive technology. Therefore, labor is omitted as a factor of production for CCS. Without loss of generality, we assume the technology is constant returns to scale in its capital infrastructure.

$\mathrm{CO}_{2}$ stock in the atmosphere increase due to net emissions a $\left(\mathrm{E}_{\mathrm{t}}-\mathrm{Y}_{\mathrm{At}}\right)$, where $\mathrm{E}_{\mathrm{t}}$ and $\mathrm{Y}_{\mathrm{At}}$ denote $\mathrm{CO}_{2}$ emissions and CCS at time $\mathrm{t}$, and a represents the uptake of emitted $\mathrm{CO}_{2}$ by the atmosphere. Furthermore, $\delta_{\mathrm{s}}$ represents the depreciation for atmospheric $\mathrm{CO}_{2}$. Additionally, we have

$$
\begin{aligned}
& \mathrm{Y}_{\mathrm{t}}=\Omega_{\mathrm{t}} \mathrm{K}_{\mathrm{Yt}_{\mathrm{t}}}^{\alpha} \mathrm{E}_{\mathrm{t}}^{\beta}\left(\mathrm{A}_{\mathrm{Yt}} \mathrm{L}_{\mathrm{Yt}}\right)^{1-\alpha-\beta} \quad\left(\lambda_{\mathrm{t}}\right) \\
& \mathrm{Y}_{\mathrm{At}}=\mathrm{A}_{\mathrm{At}} \mathrm{K}_{\mathrm{At}} \quad\left(\lambda_{\mathrm{At}}\right) \\
& \mathrm{C}_{\mathrm{t}}+\mathrm{K}_{\mathrm{Yt}+1}+\mathrm{K}_{\mathrm{At}+1}-(1-\sigma \mathrm{N})\left(\mathrm{K}_{\mathrm{Yt}}+\mathrm{K}_{\mathrm{At}}\right)=\mathrm{Y}_{\mathrm{t}}-\mathrm{qE}_{\mathrm{t}} \quad\left(\lambda_{\mathrm{Ct}}\right) \\
& \mathrm{S}_{\mathrm{t}+1}=\left(1-\delta_{\mathrm{S}}\right) \mathrm{S}_{\mathrm{t}}+\mathrm{a}\left(\mathrm{E}_{\mathrm{t}}-\mathrm{Y}_{\mathrm{At}}\right) \quad\left(\lambda_{\mathrm{St}}\right) \\
& \mathrm{L}_{\mathrm{t}+1}=\mathrm{L}_{\mathrm{t}}+\gamma_{\mathrm{L}} \mathrm{L}_{\mathrm{t}}\left(1-\mathrm{L}_{\mathrm{t}} / \mathrm{L}_{\max }\right) \\
& \mathrm{A}_{\mathrm{jt}+1}=\mathrm{A}_{\mathrm{jt}}+\gamma_{\mathrm{j}} \mathrm{A}_{\mathrm{jt}}\left(1-\mathrm{A}_{\mathrm{j} t} / \mathrm{A}_{\max }\right), \mathrm{j}=\mathrm{Y}, \mathrm{A} \\
& \mathrm{Y}_{\mathrm{At}} \geq 0\left(v_{\mathrm{At}}\right) \text { and } \mathrm{Y}_{\mathrm{At}} \leq \mathrm{E}_{\mathrm{t}} \quad\left(v_{\mathrm{CCSt}}\right)
\end{aligned}
$$

Production uses labor, capital and energy as inputs, and state of technology in the final good sector is represented by a labor productivity parameter $A_{Y t}$. Output can be used for consumption $\left(C_{t}\right)$, net investments, or energy production costs, where $\mathrm{K}_{\mathrm{Yt}}$ is the capital employed in the final good production, $\mathrm{K}_{\mathrm{At}}$, is the capital used for CCS, $\mathrm{N}$ is the number of years per period, $\sigma$ is the capital depreciation per period, and q are the energy production costs (fossil fuel extraction costs). Furthermore, $\Omega_{\mathrm{t}}=\mathrm{e}^{-\delta_{\mathrm{y}} \mathrm{S}_{\mathrm{t}} / \mathrm{S}_{0}}$ is the multiplicative-damage function as a function of the atmospheric $\mathrm{CO}_{2}$. Here, $\delta_{\mathrm{y}}$ is a positive constant and $\mathrm{S}_{\mathrm{t}}$ is the level of $\mathrm{CO}_{2}$ in the atmosphere at time $\mathrm{t}$. $\mathrm{A}_{\mathrm{At}}$ is the CCS capital productivity parameter. Labor and technological growths are represented by the logistic growth functions (see Eqs. 5 and 6). Additionally, we impose two constraints on CCS. The first one is the non-negativity constraint. The other constraint imposes that the level of CCS cannot be more than the current emissions from fossil fuel use. Therefore, there can be no capture of $\mathrm{CO}_{2}$ from the air. Lastly, the variables in parentheses on the right hand side (see Eqs. 1-7) represent the shadow prices (or the value of the Lagrange multipliers).

The first order conditions are presented below:

$$
\left(\mathrm{K}_{\mathrm{Yt}+1}\right): \mathrm{r}_{\mathrm{t}+1}+\mathrm{N} \delta_{\mathrm{S}}=\alpha \mathrm{Y}_{\mathrm{t}+1} / \mathrm{K}_{\mathrm{Yt+1}} \text {, }
$$




$$
\begin{aligned}
& \text { Cilt/Volume: } 15 \begin{array}{c}
\text { Sayı//Issue: Özel Sayı 1/Special Issue } 1 \text { Aralık/December } 2017 \\
\text { T. Durmaz } \quad \text { Doi: http://dx.doi.org/10.11611/yead. } 373460
\end{array} \\
& \left(\mathrm{~K}_{\mathrm{At}+1}\right): \mathrm{r}_{\mathrm{t}+1}+\mathrm{N} \delta_{\mathrm{S}}=\alpha \mathrm{Y}_{\mathrm{At}+1} / \mathrm{K}_{\mathrm{At}+1}, \\
& \left(\mathrm{E}_{\mathrm{t}}\right): \mathrm{q}+\mathrm{a} \tau_{\mathrm{t}}-\hat{v}_{\mathrm{CCSt}}=\beta \mathrm{Y}_{\mathrm{t}} / \mathrm{E}_{\mathrm{t}} \\
& \left(\mathrm{Y}_{\mathrm{At}}\right): \mathrm{p}_{\mathrm{At}}=\mathrm{a} \tau_{\mathrm{t}}+\hat{v}_{\mathrm{At}}-\hat{v}_{\mathrm{CCSt}}
\end{aligned}
$$

where $r_{t+1}$ is the real interest rate defined by $\lambda_{t} / \lambda_{t+1}, \tau_{t} \equiv \lambda_{s t} / \lambda_{t}$ is the unit tax on emissions, and $\mathrm{p}_{\mathrm{At}}=\lambda_{\mathrm{At}} / \lambda_{\mathrm{t}}$ is the marginal cost of CCS (in units of the final good). Furthermore, $\hat{v}_{\mathrm{At}} \equiv v_{\mathrm{At}} / \lambda_{\mathrm{t}}$ and $\hat{v}_{\mathrm{CCSt}} \equiv v_{\mathrm{CCS}} / \lambda_{\mathrm{t}}$.

When $v_{\mathrm{At}}>0$ and $v_{\mathrm{CCSt}}=0, \mathrm{p}_{\mathrm{At}}>\mathrm{a} \tau_{\mathrm{t}}$; that is, the marginal cost of CCS is higher than the unit tax on energy, and there would be no CCS. On the other hand, when $v_{\mathrm{At}}=0$ and $v_{\mathrm{CCSt}}>0, \mathrm{p}_{\mathrm{At}}<\mathrm{a} \tau_{\mathrm{t}}$; that is, the marginal cost of CCS is lower than the unit tax on energy. Therefore, it is optimal to capture and store all current emissions. Lastly, when $\mathrm{p}_{\mathrm{At}}=\mathrm{a} \tau_{\mathrm{t}}$, the rate of emissions would be between $0 \%$ and $100 \%$ of the current emissions.

We also evaluate the effects having resource and storage constraints in the economy. The reason for having such constraints is to have conclusions that are more relevant for the real life. As this is a simplification of the real world economy we are not aiming for deriving numbers that are perfectly accurate. Rather, we would like to see the implications of having such constraints on the resource use, economic growth, climate change and CCS.

\subsection{Calibration And Data For Numerical Analysis}

The time horizon we are working on is 600 years (60 periods with one period consisting of 10 years). The model is calibrated for the year 2010. The data used for the calibration is provided in the following table:

\begin{tabular}{|l|l|l|}
\hline $\mathrm{N}$ & Number of years per period & 10 \\
\hline $\mathrm{L}$ & Population in 2010 & $6.9 \mathrm{bn}$ \\
\hline $\mathrm{g}_{\mathrm{L}}$ & Population growth & 0.12 per decade \\
\hline $\mathrm{q}$ & Fossil fuel costs & $50 \mathrm{~T} \in / \mathrm{TtCO}_{2}$ \\
\hline $\mathrm{N} \delta$ & Capital depreciation & 0.7 per period \\
\hline $\mathrm{s}$ & Gross savings rate & 0.3 \\
\hline $\mathrm{S}_{0}$ & Preindustrial level of atmospheric $\mathrm{CO}_{2}$ & $275 \mathrm{ppmv}$ \\
\hline $\mathrm{a}$ & $\mathrm{CO}_{2}$ uptake rate & 0.587 \\
\hline $\mathrm{K}_{\mathrm{Y} 0}$ & Initial capital stock in the final good sector & $185 \mathrm{~T} €$ \\
\hline$\alpha$ & Capital share & 0.3549 \\
\hline$\beta$ & Energy share & 0.0249 \\
\hline
\end{tabular}


Yönetim ve Ekonomi Arastırmaları Dergisi / Journal of Management and Economics Research Cilt/Volume: 15 Sayı/Issue: Özel Sayı 1/Special Issue 1 Aralık/December 2017 ss./pp. 212-228 T. Durmaz Doi: http://dx.doi.org/10.11611/yead.373460

\begin{tabular}{|l|l|l|}
\hline$\rho$ & Utility discount rate & 0.256 per decade \\
\hline $\mathrm{A}_{\mathrm{Y} 0}$ & Final good technology level in the initial period & 240.6 \\
\hline $\mathrm{L}_{\max }$ & Maximal population & 11 billion \\
\hline $\mathrm{A}_{\mathrm{j}, \mathrm{max}}$ & Maximum technological level & 2406 \\
\hline$\gamma_{\mathrm{L}}$ & Population growth & 0.322 per decade \\
\hline$\gamma_{\mathrm{j}}$ & Rate of innovation; $\mathrm{j}=\mathrm{Y}, \mathrm{A}$ & 0.178 per decade \\
\hline$\delta_{\mathrm{S}}$ & $\mathrm{CO}_{2}$ depreciation per period & 0.0763 per decade \\
\hline
\end{tabular}

Table 1

Furthermore, $\delta_{\mathrm{y}}=0.027$. We calibrate the initial technology level for CCS, $\mathrm{A}_{\mathrm{A} 0}$, as follows. The first order condition given by Eq. 9 can equally be shown as

$$
\mathrm{A}_{\mathrm{At}+1}=\left(\mathrm{r}_{\mathrm{t}+1}+\mathrm{N} \delta\right) / \mathrm{p}_{\mathrm{At+1}} .
$$

Assuming that the interest rate equals the factor of social time preference initially (.256 in the module; constituting to $2.5 \%$ yearly), and assigning $31.7 € / \mathrm{CO}_{2}$, which approximately constitutes to $40.8 \$ / \mathrm{tCO}_{2}$ or $150 \$ / \mathrm{tC}$ (Gerlagh, 2006), we calculate that $\mathrm{A}_{\mathrm{A} 0}=0.03$. To begin with, we assign as zero value for the initial CCS capital. This overlaps with the current observation that there is no large and fully operational commercial fossil fuel power plant with CCS.

The fossil fuel resource enters the economy as follows:

$$
\mathrm{R}_{\mathrm{Et}+1}=\mathrm{R}_{\mathrm{Et}}-\mathrm{aE}_{\mathrm{t}}
$$

The reason for having the emissions, but not the level of resource use in the model is due to incorporating the amount of resource in terms of its carbon content. Doing such thing can be more in line with the model we have here. According to the IPCC Third Assessment report Climate Change 2001 -Working Group III: Mitigation, there is an estimated $5 \mathrm{TtC}$ fossil fuel reserves in the ground (Converted to $\mathrm{CO}_{2}$, this amounts to $18.350 \mathrm{TtCO}_{2}$ ). The storage data for $\mathrm{CO}_{2}$ is taken from The Bellona Foundation - Fact sheet: $\mathrm{CO}_{2}$ Storage. According to the estimates, global storage capacity is the sum of 675-900 $\mathrm{GtCO}_{2}$, which can be stored in oil and gas fields, 3-200 $\mathrm{GtCO}_{2}$ in unminable coal seams and 1000-10000 $\mathrm{GtCO}_{2}$ in deep saline formations. To calculate the number to use in the numerical analysis, I take the average of these estimates, which gives $6340 \mathrm{GtCO}_{2}$ of storage space. However, I needed to adjust these numbers to the model. The reason is when you look at the annual global emissions data for 2004, which is $0.26 \mathrm{TtCO}_{2}$ (IEA, 2006). This number compared to what we have in the calibration, 
Yönetim ve Ekonomi Arastırmaları Dergisi / Journal of Management and Economics Research

Cilt/Volume: 15 Sayı/Issue: Özel Sayı 1/Special Issue 1 Aralık/December 2017 ss./pp. 212-228

T. Durmaz Doi: http://dx.doi.org/10.11611/yead.373460

$0.179 \mathrm{TtCO}_{2}$, is higher. Hence I adjusted all the data by multiplying them with $\frac{17.96}{26}=0.69$. After adjustments, the resource stock is $12.676 \mathrm{TtCO}_{2}$ and the available storage space for CCS is $6.340 \mathrm{TtCO}_{2}$.

\section{EXOGENOUS TECHNICAL CHANGE}

In this section we assume that population and technologies follow exogenous paths (see Eqs. 5 and 6), and run six different scenarios. BAU represents Business as usual, CBA represents the planner solution, $550 \mathrm{ppmv}$ and $450 \mathrm{ppmv}$ are the planner solutions with limits on atmospheric emissions concentrations.1 Reslimit is the planner solution with a resource constraint for the exhaustible resource, while Storlimit represent storage limitation for the emissions capture through carbon capture and storage.

\section{Atmospheric $\mathrm{CO}_{2}$ concentration}

In the BAU scenario where climate change policy is absent, we see in Figure 1 that the atmospheric $\mathrm{CO}_{2}$ concentration is continuously growing. In the two stabilization scenarios, atmospheric $\mathrm{CO}_{2}$ concentrations are stabilized at $450 \mathrm{ppmv}$ and $550 \mathrm{ppmv}$. The CBA, Reslimit and Storlimit scenarios result in quite similar concentration trajectories until the storage limit is reached in the Storlimit scenario.

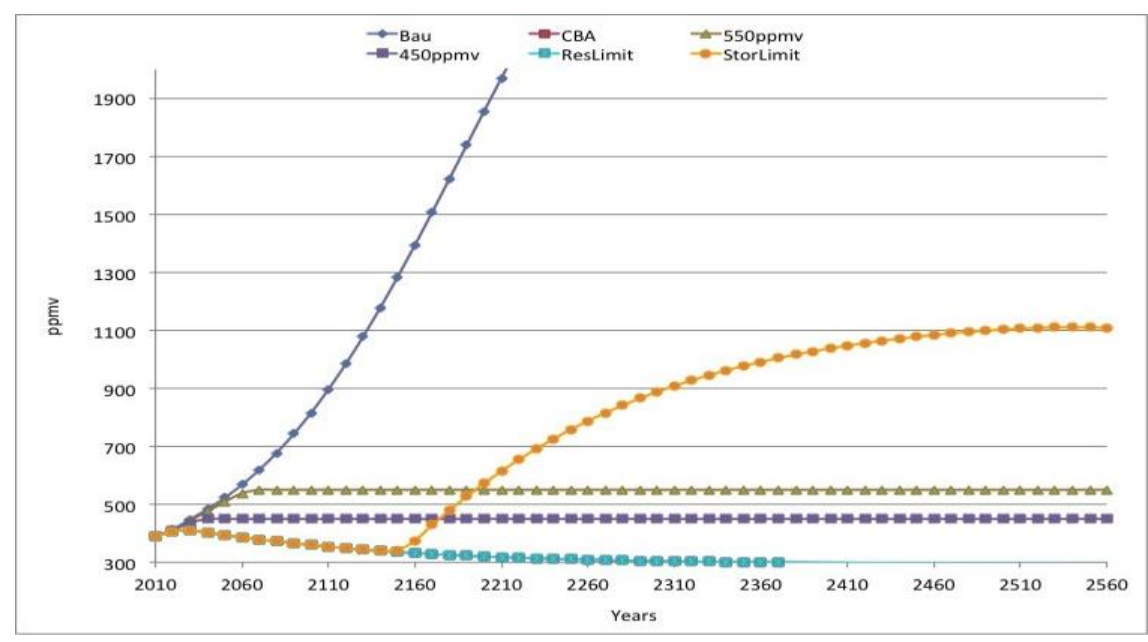

Figure 1

\section{Carbon capture and sequestration}

At a first glance we see the role CCS plays once it is available. In every scenario we see that it is optimal to capture and store carbon. In the stabilization scenarios, CCS has a smaller role to play. In the Storlimit case, the available storage for $\mathrm{CO}_{2}$ vanishes around year 2150; therefore CCS cannot be 
Yönetim ve Ekonomi Araștırmaları Dergisi / Journal of Management and Economics Research Cilt/Volume: 15 Sayı/Issue: Özel Sayı 1/Special Issue 1 Aralık/December 2017 ss./pp. 212-228 T. Durmaz Doi: http://dx.doi.org/10.11611/yead.373460

active anymore after this point. Although the ratio of CCS seems high in Reslimit case, the level is getting smaller in time due to diminishing levels of the exhaustible resource. The graph for CCS with the levels is given in Figure 3.

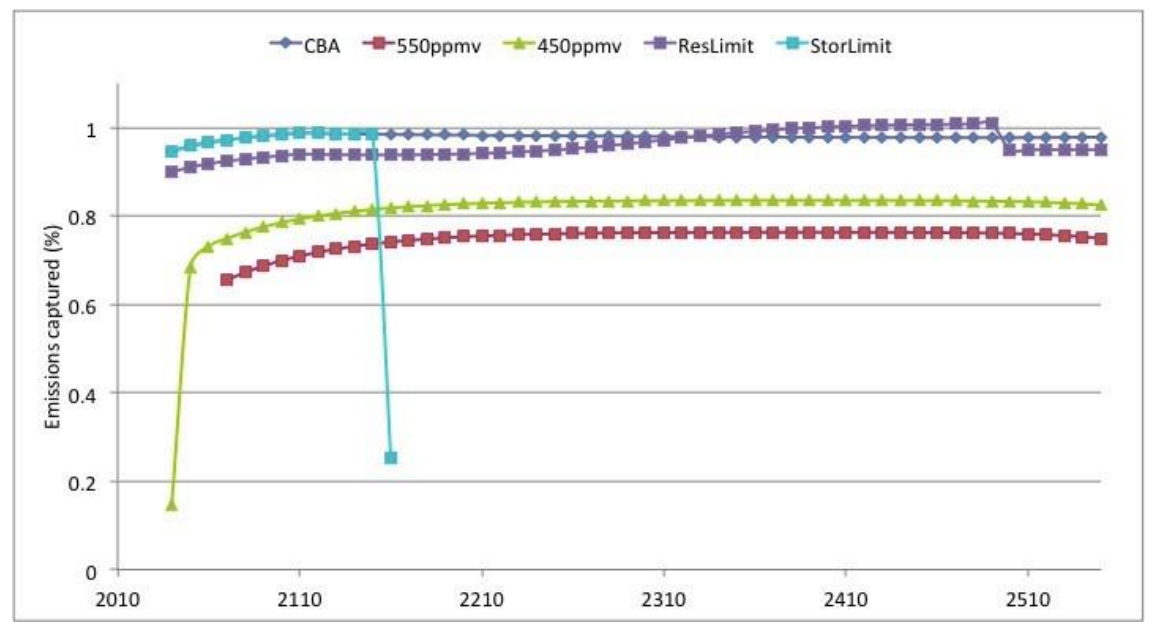

Figure 2

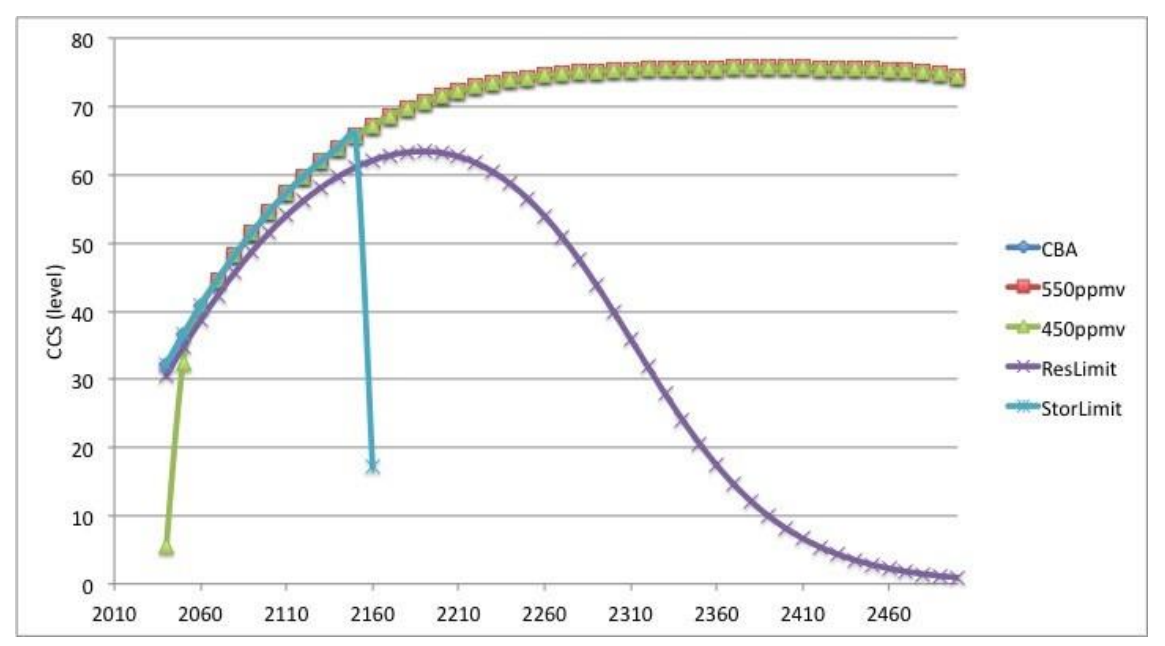

Figure 3

\section{Tax rate}

As is seen in 4 the tax on the final good is increasing continuously. For the stabilization scenarios the tax is lower as emissions cannot pass the stabilizers of 450 and 550ppmv. Within the limited resource case, we see that the tax gets lower than the corresponding trajectories coming from the CBA and Storlimit scenarios as the resource use diminishing, resulting in lower emissions. 
Yönetim ve Ekonomi Arastırmaları Dergisi / Journal of Management and Economics Research Cilt/Volume: 15 Sayı/Issue: Özel Sayı 1/Special Issue 1 Aralık/December 2017 ss./pp. 212-228 T. Durmaz Doi: http://dx.doi.org/10.11611/yead.373460

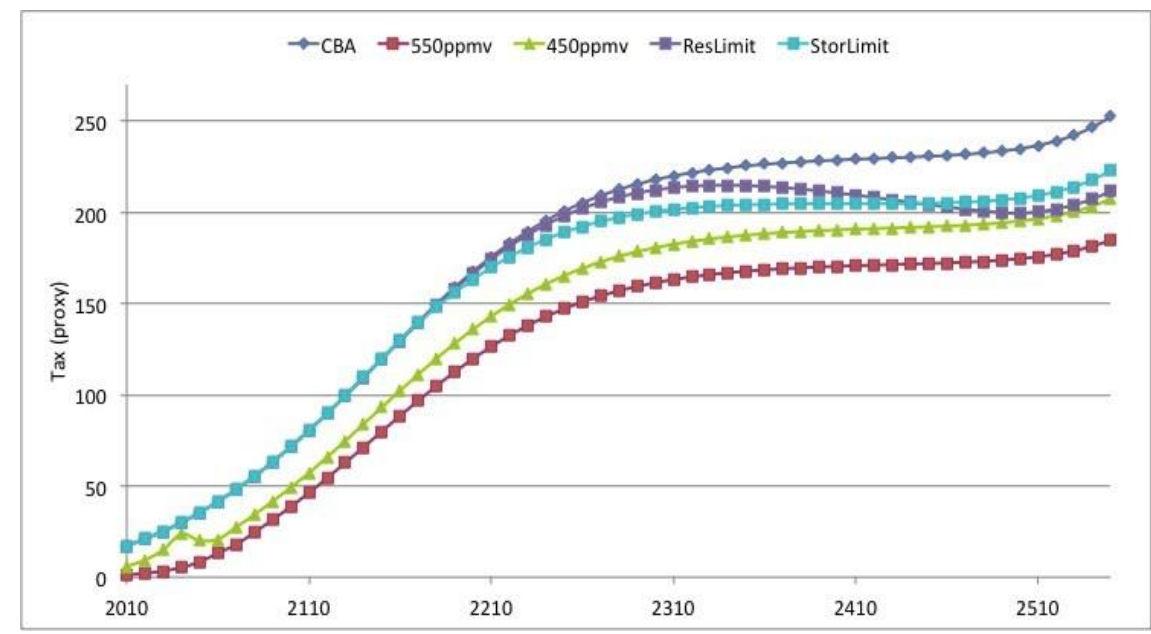

Figure 4

\section{Output growth, consumption and welfare}

There is a downward trend in the growth rates in the economy. This is a natural result of the fact that there is no non-carbon technology to switch to; hence the only way forward is to emit as low emissions as possible by contracting the economy or do as much CCS as possible (which will also put a burden on the growth rates). A closer look at Figure 5 reveals that the growth rates are quite similar except the BAU case, where the growth is relatively higher initially but gets lower in a short period of time.

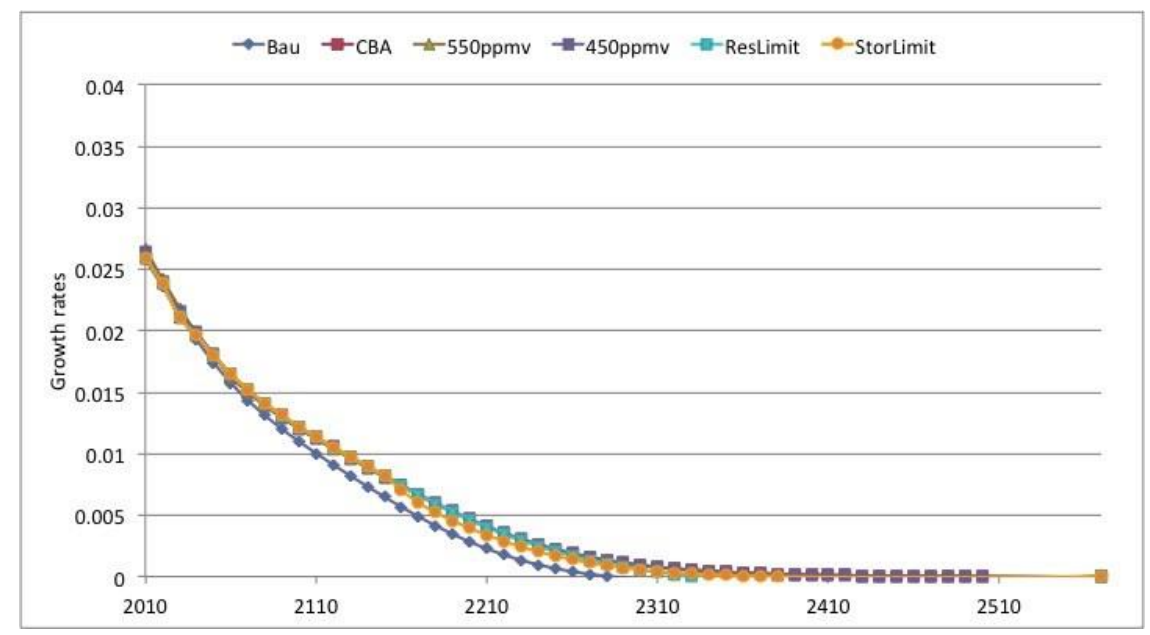

Figure 5

The consumption levels show rather a clearer picture in terms of the differences. We see the long run effect of the exhaustible resource constraint, which results in lower consumption. The limited storage case is also causing lower consumption though the level manages to get higher than the limited 
Yönetim ve Ekonomi Araștırmaları Dergisi / Journal of Management and Economics Research

Cilt/Volume: 15 Sayı/Issue: Özel Sayı 1/Special Issue 1 Aralık/December 2017 ss./pp. 212-228

T. Durmaz Doi: http://dx.doi.org/10.11611/yead.373460

resource case in the very long run. The consumption level is hit hard in the BAU case due to high damages coming from global warming.

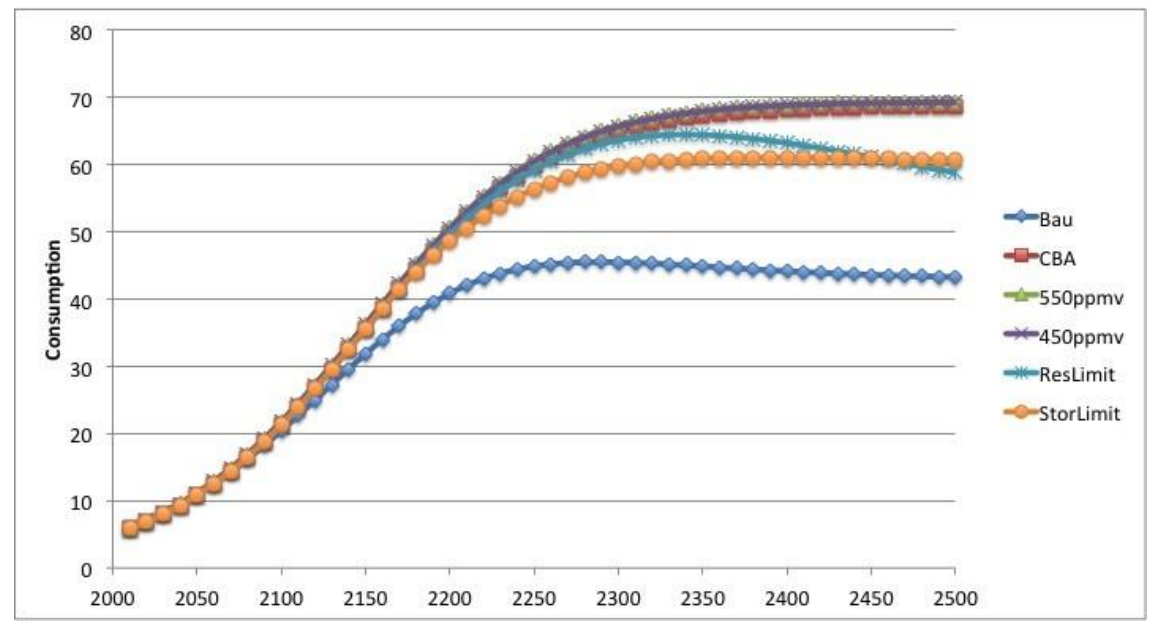

Figure 6

The welfare levels show a similar pattern to consumption levels. The ranking for the total welfare among the scenarios is as follows: $\mathrm{W}_{\mathrm{BAU}}<\mathrm{W}_{\text {StorLimit }}<\mathrm{W}_{\text {ResLimit }}<\mathrm{W}_{\mathrm{CBA}}<\mathrm{W}_{450 \mathrm{ppmv}}<\mathrm{W}_{550 \mathrm{ppmv}}$. The intuition for Storlimit giving the second lowest total welfare is related to the unavailability of CCS in the long run. For this reason, more sacrifice in growth needs to be made relative to other scenarios except BAU. The results also show that the limited resource has a smaller adverse effect than the limited storage case, which we find rather surprising.

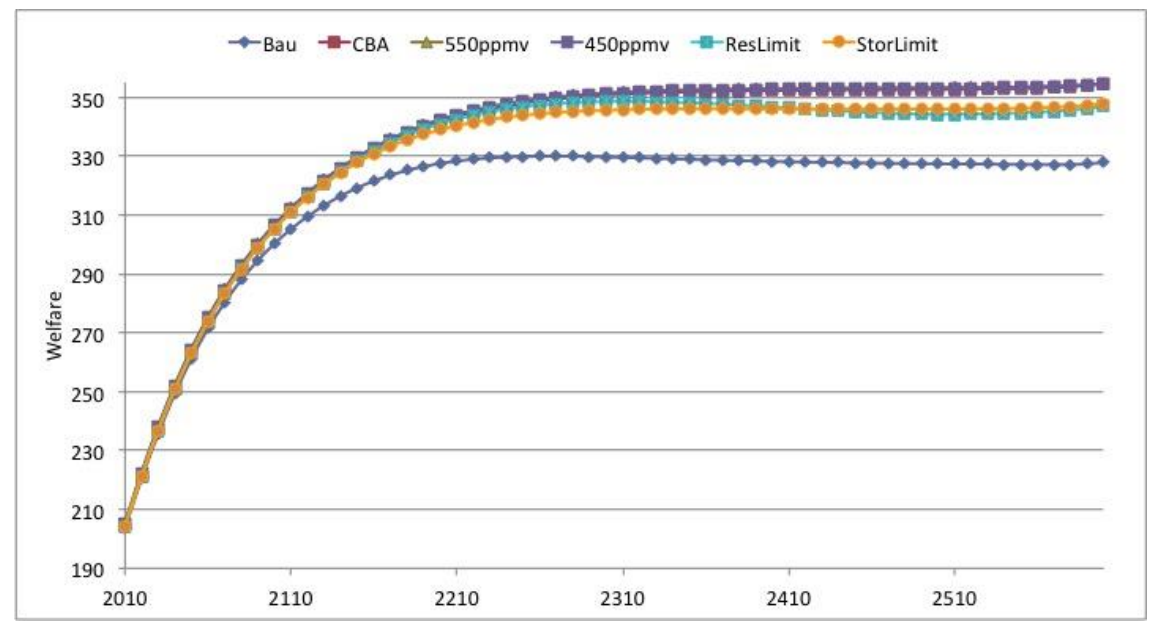

Figure 7 
Yönetim ve Ekonomi Araștırmaları Dergisi / Journal of Management and Economics Research

Cilt/Volume: 15 Sayı/Issue: Özel Sayı 1/Special Issue 1 Aralık/December 2017 ss./pp. 212-228

T. Durmaz Doi: http://dx.doi.org/10.11611/yead.373460

\section{ENDOGENOUS TECHNICAL CHANGE}

In this section we abstract from scenarios such as limited exhaustible resource and storage capacity. Instead, we focus on the role of endogenous technical change given the CCS technology and the two $\mathrm{CO}_{2}$ stabilization targets. The source of endogenous technical change comes from $\mathrm{R} \& \mathrm{D}$ investments in labor-augmenting and CCS technologies, RY and RA, respectively. As a result the total $R \& D$ spending, $R$, is the total of these two $R \& D$ investments,

$$
\mathrm{R}_{\mathrm{t}}=\mathrm{R}_{\mathrm{Yt}}+\mathrm{R}_{\mathrm{At}} \cdot \quad\left(\lambda_{\mathrm{Rt}}\right)
$$

$R \& D$ expenditures determines the knowledge level in the next period

$$
\mathrm{A}_{\mathrm{jt}+1}=\mathrm{A}_{\mathrm{jt}}+\frac{\theta+1}{\theta} R_{j t^{\frac{\theta}{\theta+1}}}, \mathrm{j}=\mathrm{Y}, \mathrm{A} \quad\left(\mu_{\mathrm{jt}}\right)
$$

The new budget equations is,

$$
\mathrm{C}_{\mathrm{t}}+\mathrm{K}_{\mathrm{Yt}+1}+\mathrm{K}_{\mathrm{At}+1}+\mathrm{R}_{\mathrm{t}}-(1-\sigma \mathrm{N})\left(\mathrm{K}_{\mathrm{Yt}}+\mathrm{K}_{\mathrm{At}}\right)=\mathrm{Y}_{\mathrm{t}}-\mathrm{qE}_{\mathrm{t}} \quad\left(\lambda_{\mathrm{Ct}}\right)
$$

First order conditions with respect to R\&D investment and accumulated knowledge levels, $R_{\mathrm{jt}}$ and $\mathrm{A}_{\mathrm{jt}+1}$ respectively, are

$$
\begin{aligned}
& \left(\mathrm{R}_{\mathrm{jt}}\right): \lambda_{\mathrm{t}}=\mu_{\mathrm{jt}} R_{j t}^{-\frac{1}{\theta+1},} \\
& \left(\mathrm{~A}_{\mathrm{Yt}+1}\right): \mu_{\mathrm{Yt}}=\mu_{\mathrm{Yt}+1}+\lambda_{\mathrm{t}+1} \mathrm{Y}_{\mathrm{t}+1} / \mathrm{A}_{\mathrm{Yt}+1}, \\
& \left(\mathrm{~A}_{\mathrm{At}+1}\right): \mu_{\mathrm{At}}=\mu_{\mathrm{At}+1}+\lambda_{\mathrm{At}+1} \mathrm{Y}_{\mathrm{At}+1} / \mathrm{A}_{\mathrm{At}+1},
\end{aligned}
$$

We display five different scenarios in the following figures. The first one is the BAU scenario with exogenous technical change. Then we have the first-best solution given exogenous technical change (CBAExo). Following this we have the first-best solution with endogenous change (CBAEndo). The last two scenarios are the ones with the 450 and 550 ppmv stabilization targets.

\section{Atmospheric $\mathrm{CO}_{2}$ concentration}

The surprising result here is that the lowest concentration of $\mathrm{CO}_{2}$ occurs in $\mathrm{CBAExo}$. This is due to the consumption - climate change trade-off. A stronger growth due to endogenous technological change may make it more beneficial to produce more and at the same time emit more $\mathrm{CO}_{2}$. Though, this needs further evaluation and this is what we are going to do in the following.

\section{Carbon capture and sequestration}

In Figure 9 we see that the level of $\mathrm{CO}_{2}$ captured do not differ significantly between different scenarios. However, what cause the difference between the scenarios in Figure 10 are the emission 
Yönetim ve Ekonomi Araștırmaları Dergisi / Journal of Management and Economics Research Cilt/Volume: 15 Sayı/Issue: Özel Sayı 1/Special Issue 1 Aralık/December 2017 ss./pp. 212-228 T. Durmaz Doi: http://dx.doi.org/10.11611/yead.373460

trajectories (see Figure 11).

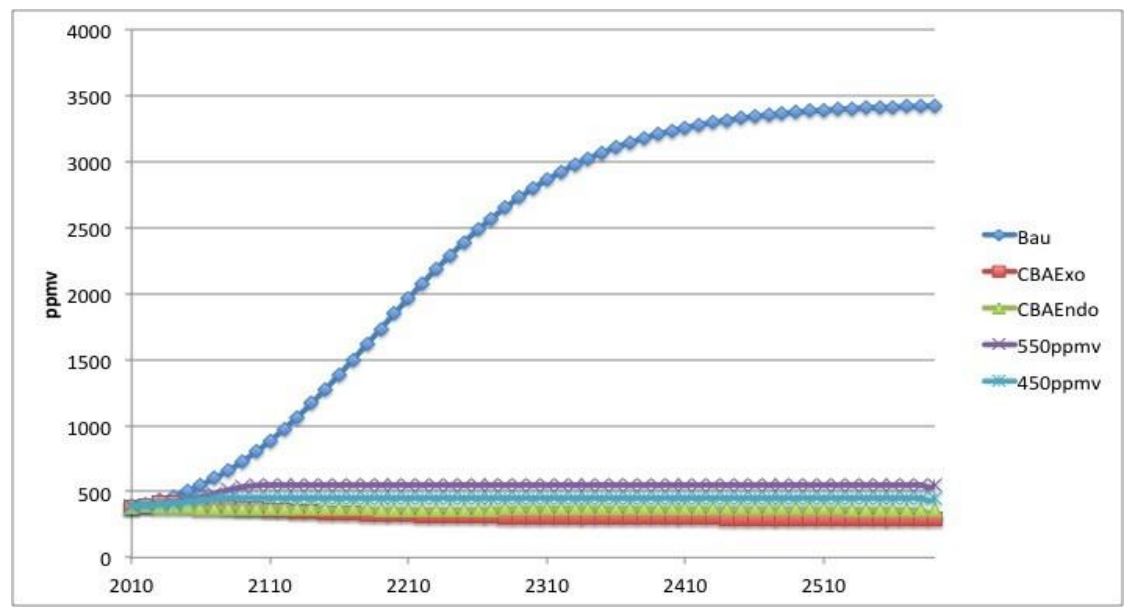

Figure 8

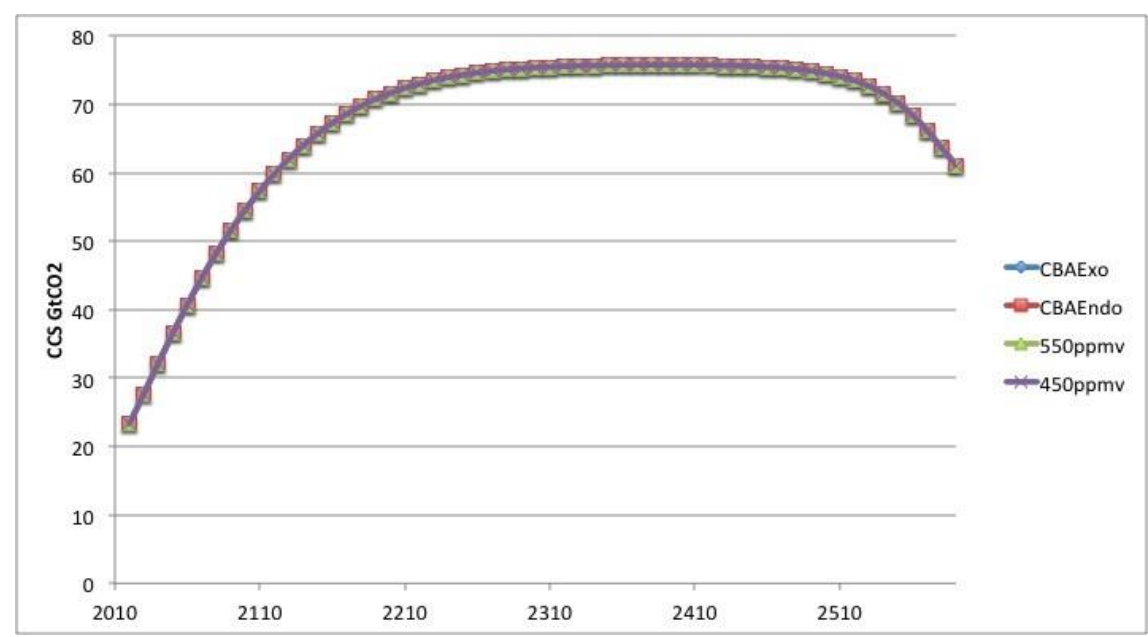

Figure 9

In Figure 11 we see that a strong presence of green paradox exists: the stabilization targets result in emissions to rise in the early periods. In the exogenous technical change scenario, the ratio of CCS to emissions is rather high but stable. We do see a weaker presence of green paradox in CBAEndo as there are no predetermined atmospheric $\mathrm{CO}_{2}$ ceilings. 
Yönetim ve Ekonomi Arastırmaları Dergisi / Journal of Management and Economics Research Cilt/Volume: 15 Sayı/Issue: Özel Sayı 1/Special Issue 1 Aralık/December 2017 ss./pp. 212-228 T. Durmaz Doi: http://dx.doi.org/10.11611/yead.373460

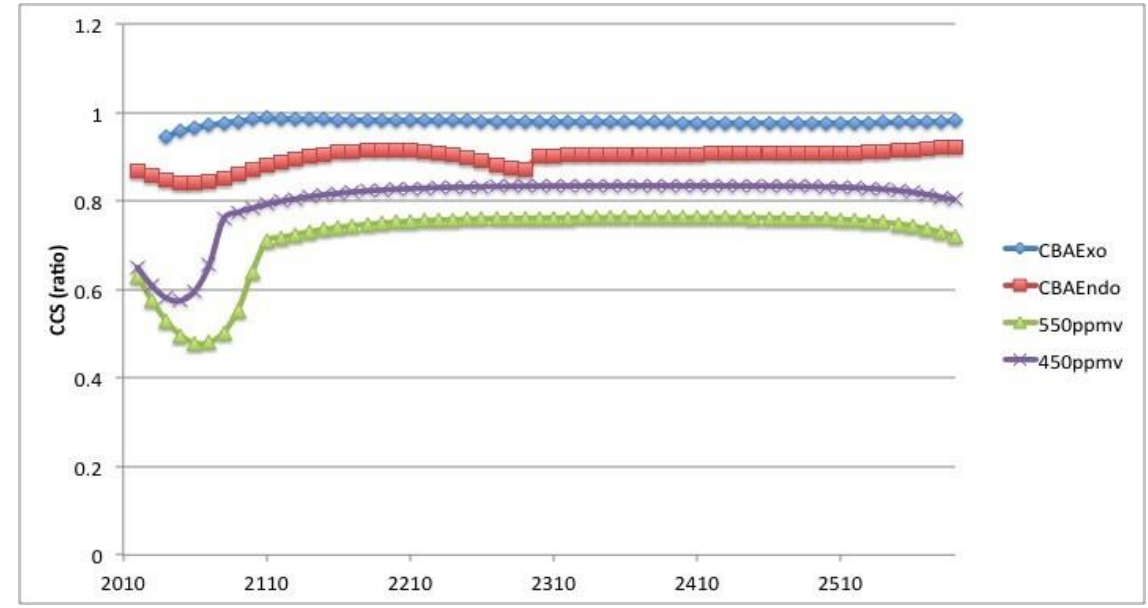

Figure 10

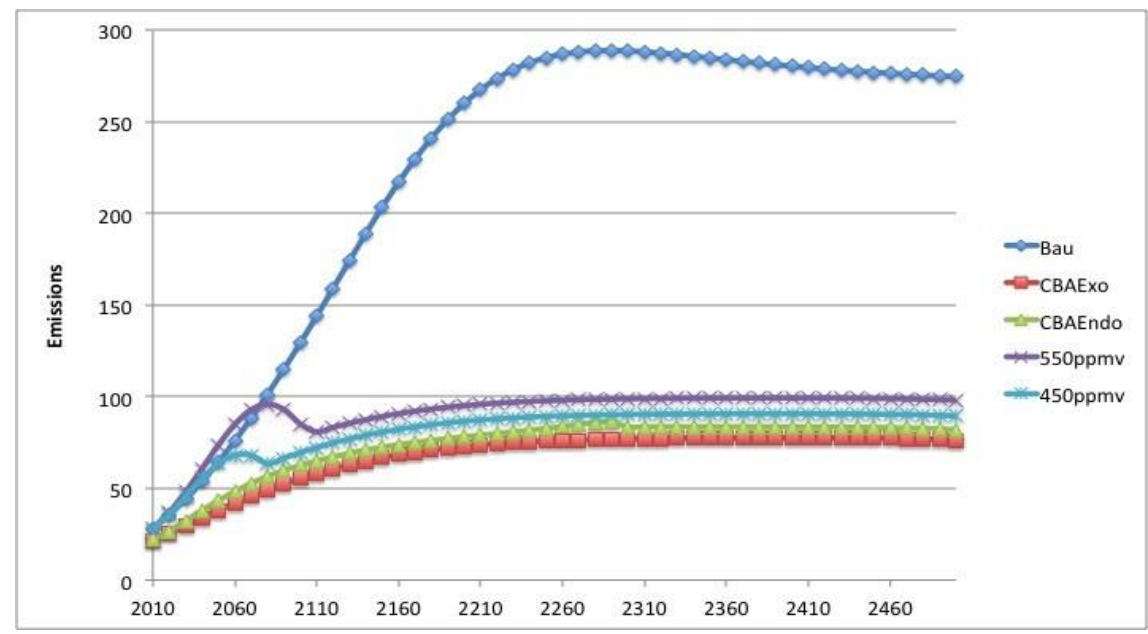

Figure 11

\section{Tax rates}

We see a stronger downward effect on taxes in the endogenous technical change case. Ac- cording to this, the tax on final good stays almost constant after 2270 . This can be easily seen from stable emission levels and high carbon capture and storage activity corresponding to these emissions. The tax levels are slightly lower than the corresponding tax levels in the first section. 
Yönetim ve Ekonomi Araștırmaları Dergisi / Journal of Management and Economics Research Cilt/Volume: 15 Sayı/Issue: Özel Sayı 1/Special Issue 1 Aralık/December 2017 ss./pp. 212-228 T. Durmaz Doi: http://dx.doi.org/10.11611/yead.373460

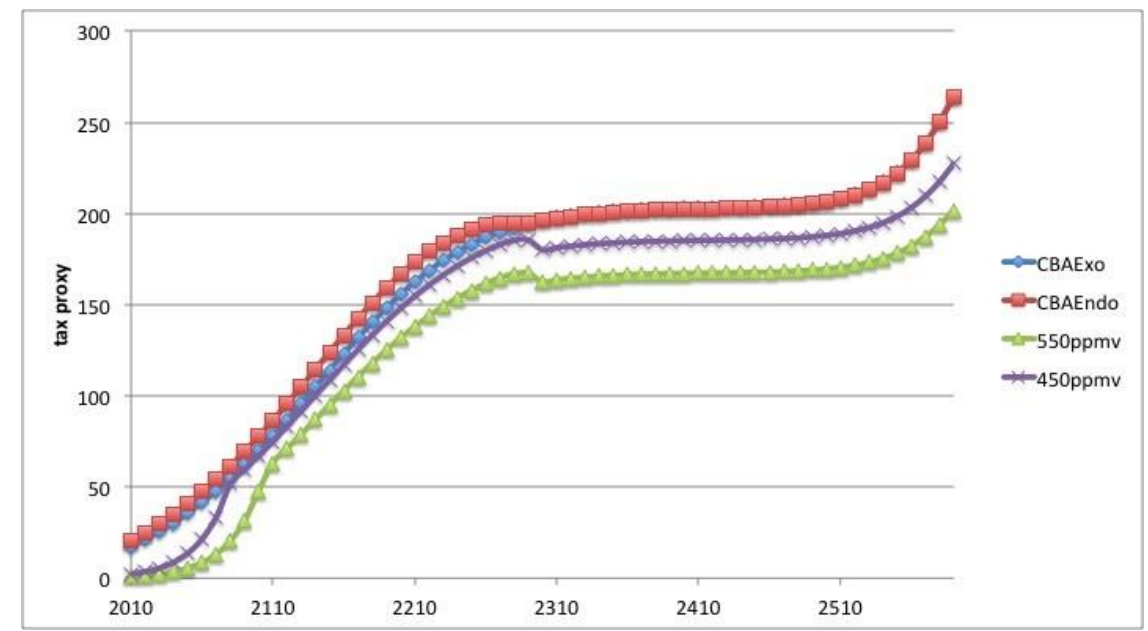

Figure 12

\section{Output growth, consumption and welfare}

The striking part is coming from the differences in growth rates and consumption levels. We witness strictly higher levels of growth for all the endogenous growth scenarios. This implies the importance of R\&D activity and hence the endogenous growth.

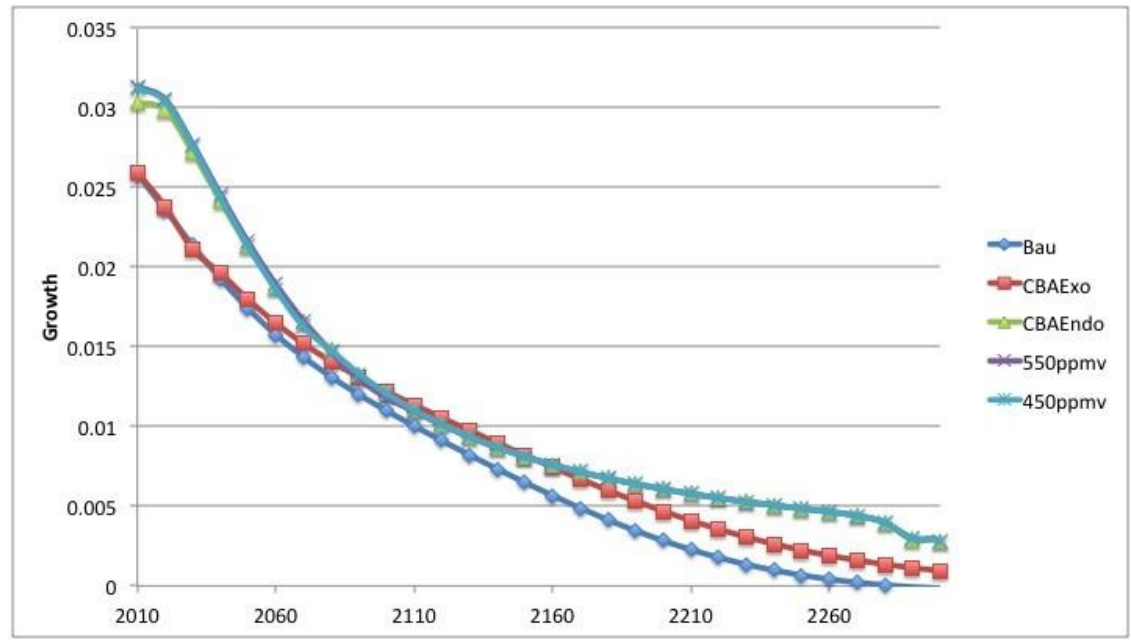

Figure 13

When we look at the levels of consumption (Figure 14) we observe that the optimal levels of consumption for the endogenous growth scenarios are twice the amount of the optimal consumption level in the exogenous growing technologies case. All of the scenarios give much higher levels of consumption compared to the BAUscenario. 
Yönetim ve Ekonomi Araștırmaları Dergisi / Journal of Management and Economics Research Cilt/Volume: 15 Sayı/Issue: Özel Sayı 1/Special Issue 1 Aralık/December 2017 ss./pp. 212-228 T. Durmaz Doi: http://dx.doi.org/10.11611/yead.373460

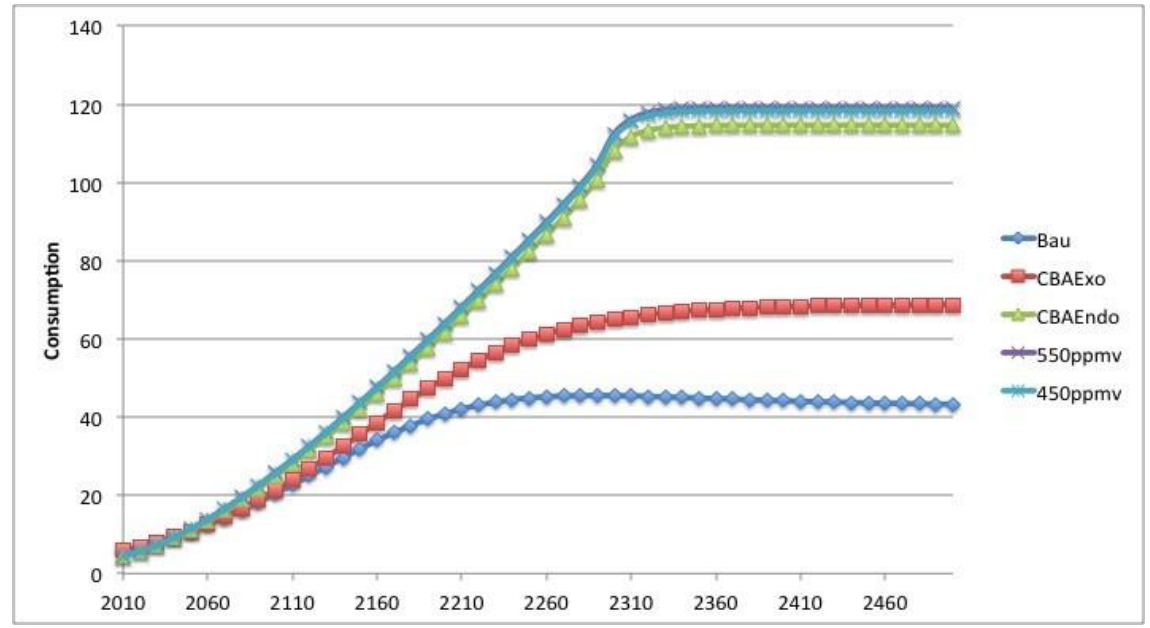

Figure 14

In Figure (15), we almost see the reflection of consumption levels; though the levels are scaled downward due to the logarithmic utility function

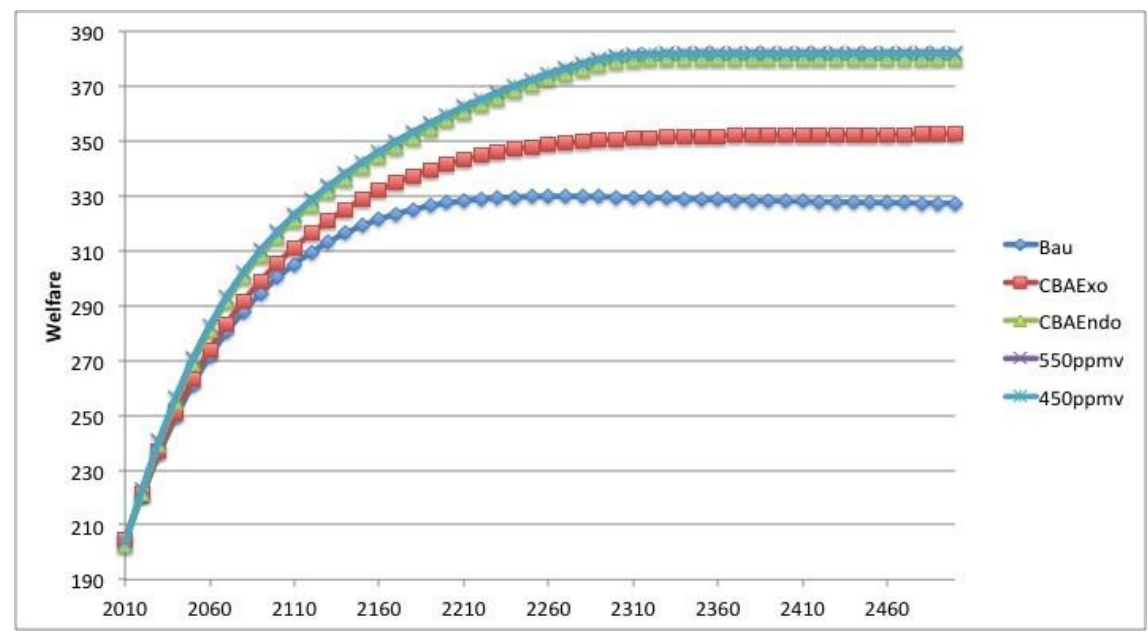

Figure 15

\section{CONCLUSION}

In this paper, we attempted to evaluate CCS technology both in exogenous and endogenous growth models with environmental constraints. According to the findings, the level of CCS is not significantly affected by the fact that technology is taken exogenous or endogenous. This may actually imply that instead of focusing on R\&D spending for the technology, we may focus on the effects of learning-by-doing on the technology. As the technology is not productive (i.e., does use the final good), 
Yönetim ve Ekonomi Arastırmaları Dergisi / Journal of Management and Economics Research

Cilt/Volume: 15 Sayı/Issue: Özel Sayı 1/Special Issue 1 Aralık/December 2017 ss./pp. 212-228

T. Durmaz Doi: http://dx.doi.org/10.11611/yead.373460

it may be of relevance to focus on perfecting the process itself. (This is actually the case in reality. Given their experiences, people working on CCS say that experience, rather than R\&D investments, play a bigger role in making the technology cheaper). This may explain the reason why the technology receives so little $R \& D$ investments in the results we have. Moreover, in all of the scenarios, we witnessed that CCS was employed. Therefore, there is no question about its welfare enhancing effect. In the exogenous growth case, all the results are as expected although it is rather hard to interpret the increasing atmospheric concentration of $\mathrm{CO}_{2}$ when storage availability for $\mathrm{CO}_{2}$ runs out. We did witness the presence of the green paradox in the endogenous growth case, although this effect is not present for the exogenous growth counterpart.

Before we had started working on this study, we had different research questions in mind. One was related to the political will of holding on to the optimal tax rates. Hence the question was about the effect of future uncertainties in tax rates on today's investments and activities in CCS. Although the trajectories in both the exogenous and endogenous technological change (exotech and endotech)) cases look similar for CCS, we do actually see differences in emission levels. For example, in 2300 the emissions in in exotech and endotech are 76.9 and $83.5 \mathrm{GtCO}_{2}$, respectively. Depending on different scenarios, CCS rates start from $75 \%$ and gets higher, implying significant contribution to the abatement efforts. As the economies are, from an empirical point of view, more in favor of technical changes induced by prices, un- certain future tax rates can have significant effects on use of and investments made in CCS. Therefore, we believe this issue needs a closer look. Moreover, the storage issues for $\mathrm{CO}_{2}$ captured may have some relevance. We think Figure (1) deserves a better understanding for this case. Besides, leakage possibilities can be discouraging for the technology. As we have also showed in the first section, there is a highly significant effect of an exhaustible resource on the level of CCS activity. This brings with it the question why there is so much investments going on for a technology that is dependent on an exhaustible resource.

In conclusion, uncertainty in the future political wills towards CCS, storage problems and limited resource availability may require further investigation for the technology. As being a carbonfree technology, and hence has the potential to compete with other carbon-free technologies, the analysis can become more interesting to look at these problems in a bigger model with more technological choices, different factors of production and a more detailed description of the environment. However, if we think that the very strong dependence on fossil fuels will carry on, the results we have in this study can have important policy implications. 
Yönetim ve Ekonomi Araștırmaları Dergisi / Journal of Management and Economics Research

Cilt/Volume: 15 Sayı/Issue: Özel Sayı 1/Special Issue 1 Aralık/December 2017 ss./pp. 212-228

T. Durmaz Doi: http://dx.doi.org/10.11611/yead.373460

\section{REFERENCES}

Gerlagh, R. (2006). ITC in a Global Growth-Climate Model with CCS: The Value of Induced Technical Change for Climate Stabilization. The Energy Journal (Special Issue), 223-240.

Golombek, R., M. Greaker, S. A. Kittelsen, O. Rogeberg, and F. R. Aune (2011). Carbon Capture and Storage Technologies in the European Power Market. Energy Journal (32), 209-238.

IEA (2006). World energy outlook. Technical report, International Energy Agency.

IEA (2009). Technology roadmap carbon capture and storage. Technical report, International Energy Agency.

IEA (2013). Technology Roadmap: Carbon Capture and Storage. Technical report, International Energy Agency.

IEA (2014). $\mathrm{CO}_{2}$ Emissions from Fuel Combustion - Highlights. Technical report, International Energy Agency.

IPCC (2005). IPCC Special Report on Carbon Dioxide Capture and Storage. Prepared by Working Group III of the Intergovernmental Panel on Climate Change, Cambridge University Press, Cambridge, United Kingdom and New York, NY, USA.

Metz, B., O. Davidson, H. de Coninck, M. Loos, and L. Meyer (2005). Carbon dioxide capture and storage. Technical report, IPCC.

Tjernshaugen, A. (2008). Political Commitment to $\mathrm{CO}_{2}$ Capture and Storage: Evidence from Government RD\&D Budgets. Mitigation and Adaptation of Strategies for Global Change 13, 121.

UNEP (2006). Can carbon dioxide storage help cut greenhouse emissions? A simplified guide to the IPCC's 'Special Report on Carbon Dioxide Capture \& Storage'. IPCC. 